\title{
PEMERINTAHAN DAN BIROKRASI
}

\author{
Desriadi \\ Universitas Islam Kuantan Singingi \\ desco_paliang@ymail.com
}

\begin{abstract}
Karl Marx states that bureaucracy is a parasitic and exploitative organization. Bureaucracy is an instrument for the powerful class to exploit other social groups of people (in their authority). Bureaucracy functions to maintain the privilege and status quo of the capitalist class. On the other hand, Hegel states that bureaucracy is a system created by the have class to deceive the lower classes to maintain and increase their own welfare. In this case bureaucracy becomes the scapegoat for all mistakes of the ruler toward the people. The whole mistakes of the ruler will finally come back to the bureaucracy which is only an instrument.

Hegel explains that bureaucracy is an institution which occupies a neutral organic position in a social structure and it functions as a link in a country in manifesting the general needs civil society which represents special needs. Hegel sees that bureaucracy is bridge created to link different kinds of needs of people and state. Therefore the role of bureaucracy is very significant in unifying the perceptions and perspectives among countries and people in order to avoid a chaos happen.
\end{abstract}

Keywords: governance, bureaucracy

\begin{abstract}
Abstrak
KARL MARX mengatakan Birokrasi adalah Organisasi yang bersifat Parasitik dan Eksploitatif. Birokrasi merupakan Instrumen bagi kelas yang berkuasa untuk mengekploitasi kelas sosial yang lain (yang dikuasai). Birokrasi berfungsi untuk mempertahankan privilage dan status quo bagi kepentingan kelas kapitalis. Dalam pandangan Marx yang berbeda dengan Hegel, birokrasi merupakan sistem yang diciptakan oleh kalangan atas (the have) untuk memperdayai kalangan bawah (the have not) demi mempertahankan dan meningkatkan kesejahteraan mereka sendiri. Dalam hal ini birokrasi menjadi kambing hitam bagi kesalahan penguasa terhadap rakyatnya. Segenap kesalahan penguasa akhirnya tertumpu pada birokrasi yang sebenarnya hanya menjadi alat saja.

HEGEL mengatakan Birokrasi adalah institusi yang menduduki posisi organik yang netral di dalam struktur sosial dan berfungsi sebagai penghubung antara negara yang memanifestasikan kepentingan umum, dan masyarakat sipil yang mewakili kepentingan khusus dalam masyarakat. Hegel melihat, bahwa birokrasi merupakan jembatan yang dibuat untuk menghubungkan antara kepentingan masyarakat dan kepentingan negara yang dalam saat-saat tertentu berbeda. Oleh sebab itu peran birokrasi menjadi sangat strategis dalam rangka menyatukan persepsi dan perspektif antara negara (pemerintah) dan masyarakat sehingga tidak terjadi kekacauan.
\end{abstract}

Kata Kunci: pemerintahan dan birokrasi 


\section{A. Pendahuluan}

Marxis bisa menerima konsep pemikiran Hegel tentang ketiga aktor tersebut, yakni birokrasi, kepentingan partikular, dan kepentingan general (pemerintah). Akan tetapi menurut Karl Marx birokrasi itu bukannya mewakili asli dirinya sendiri. Marx berpendapat negara itu bukan mewakili kepentingan umum. Tidak ada kepentingan umum (general) itu, yang ada ialah kepentingan partikular (kepentingan pribadi) yang mendominasi kepentingan partikular lainnya. Kepentingan partikular yang memenangkan perjuangan klas sehingga menjadi klas yang dominan itulah yang berkuasa. Birokrasi menurut Karl Marx merupakan suatu kelompok partikular yang sangat spesifik. Birokrasi bukanlah klas masyarakat, walaupun eksistensinya berkaitan dengan pembagian masyarakat ke dalam klas - klas tertentu. Lebih tepatnya, menurut Karl Marx (dalam Thoha 2014 : 23) birokrasi adalah negara atau pemerintah itu sendiri. Birokrasi merupakan instrumen yang dipergunakan oleh kelas yang dominan untuk melaksanakan kekuasaan dominasinya atas kelas - kelas sosial lainnya. Dengan kata lain birokrasi memihak kepada kelas partikular yang mendominasi tersebut.

Berdasarkan konsep pemikiran seperti itu, maka birokrasi itu sendiri pada tingkatan tertentu mempunyai hubungan yang sangat erat dengan kelas yang dominan dan pada pemerintah. Eksistensi birokrasi sangat tergantung pada kelas dominan dan pada pemerintah. Konsep pemikiran Karl Marx dan Hegel dalam konteks pengembangan kekuatan politik dalam birokrasi pemerintah seperti yang banyak dianut oleh pemerintahan yang demokratis, dapat dijadikan suatu perbandingan. Kekuatan politik yang datang dan pergi sebagai kelompok yang menguasai pemerintahan dan birokrasi sebagai pelaksana kebijakan pemerintahan merupakan dua hal yang tidak bisa dipisahkan, akan tetapi dapat dibedakan. Konsep Marx menunjukkan bahwa keberadaan birokrasi pemerintah memihak pada kekuatan politik yang memerintah. Sedangkan Hegel sebaliknya berada di tengah - tengah sebagai mediator yang menghubungkan kedua kepentingan general (pemerintah) dan partikular (kekuatan politik dalam masyarakat). Dengan kata lain birokrasi Hegelian menekankan posisi birokrasi netral terhadap kekuatan - kekuatan masyarakat lainnya.

Secara faktual, birokrasi menghadapi sejumlah masalah yang kerap kali menjadi rintangan dalam pencapaian tujuan, diantaranya adalah sebagai berikut :

a. Proses pekerjaannya seringkali tidak dapat diperkirakan dan langkah yang diambil oleh birokrasi juga terkesan lamban;

b. Menunjukkan favoritisme dalam perlakuannya terhadap klien tertentu dan diskriminasi pada yang lain; 
c. Memperkerjakan staff yang menunjukkan ketertarikan yang rendah terhadap standar profesional dan kualitas pelayanan program;

d. Mempromosikan staff berdasarkan favoritisme politis atau kriteria yang tidak profesional;

e. Menciptakan timbunan kertas yang tidak berguna dan tidak mampu menyesuaikan diri secara relevan dengan perkembangan sosial.

Dalam kaitan ini, maka birokrasi merupakan salah satu sistem yang spesifik dari proses general dari pemisahan (the general process of alienation). Konsep alinasi ini merupakan pusat dari pemikiran Marxis. Melalui proses alinasi ini kekuatan - kekuatan sosial itu lari atau menghindari dari pengawasan dari individu manusia. Kekuatan sosial ini mencoba hidup independen yang pada gilirannya mengubah dirinya sebagai kekuatan yang melawan manusia atau menentang pendirinya. Arti filosofi dari proses alinasi ini jika diterapkan dalam kasus birokrasi sangat menakjubkan. Menurut Marx birokrasi lalu menjadi kekuatan yang otonomi dan opresif yang dirasakan oleh mayoritas rakyat atau masyarakat sebagai kekuatan yang misterius. Betapa tidak, disatu pihak birokrasi berbuat baik mengatur kehidupan rakyat akan tetapi dipihak lain kekuatan itu diluar jangkauan rakyat untuk bisa mengontrolnya. Jika demikian keadaan birokrasi maka birokrasi itu menjadi kekuatan yang tertutup, sejenis dengan kekuatan penjaga istana yang penuh hak prerogatif, angker, dan keras.

Proses alinasi itu tidak hanya terbatas pada pemisahan antara birokrasi dengan dunia luarnya (rakyat), akan tetapi juga pemisahan antara kekuatan di dalam birokrasi sendiri. Birokrasi tidak hanya menutup diri dan bersembunyi terpisah dengan kekuatan nonbirokrasi saja, akan tetapi juga dia bersembunyi di dalam dirinya sendiri. Seringkali terjadi bahwa birokrasi tidak menyadari ada kekuatan parasit yang menggerogoti pekerjaan atau dirinya sendiri. Kekuatan - kekuatan parasit ini kemudian mengonsolidasi dirinya di dalam birokrasi melalui tata jenjang hierarki dan disiplin yang kaku serta kemamfaatan kewenangan yang melekat pada sistem birokrasi.

Selain proses alinasi baik dari kekuatan luar (rakyat) maupun dari dalam dirinya sendiri, maka konsep birokrasi Marxis juga menampilkan ketidakmampuan (incompetence) dari birokrasi. Karl Marx menekankan bahwa birokrasi itu kurang mengemukakan inisiatif dan imajinasi, dan tidak adanya keberanian mengambil resiko pertanggungjawaban. Selain itu birokrasi berusaha secara terus - menerus untuk mempertahankan dan memperpanjang fungsi 
dominasinya agar bisa mengonsolidasikan posisi dan hak - hak prerogatifnya. Marx menamakan kesatuan birokrasi seperti itu semacam bentuk imperalisme - birokratik (bureaucratic imperalism). Para birokrasi menyakinkan dirinya bahwa dia mempunyai fungsi yang berguna dan bermamfaat untuk melaksanakan kewajibannya. Lebih dari itu, menurut Marx upaya untuk menjadikan birokrasi menjadi self aggrandisement disertai dengan materialisme yang buruk (sordid materialism) dari birokrasi. Hal semacam ini dicontohkan oleh Karl Marx upaya birokrasi dalam internal struggle untuk memperoleh promosi, pengembangan karier, status, dan priviligis.

\section{B. Kerangka Teoritis}

Birokrasi menurut Karl Marx merupakan instrumen kelas kapitalis. Oleh karena itu melalui revolusi proletariat dan kehadiran kelas - kelas di dalam masyarakat maka negara dan birokrasinya akan dihancurkan. Menurut Karl Marx di dalam masyarakat komunis itu, tidak ada eksploitasi dan pembagian sosial maka keberadaan birokrasi itu merupakan upaya tidak ada artinya karena redundant (mubazir). Oleh karena itu, hancurnya birokrasi itu harus dipahami sebagai proses penyerapan gradual birokrasi ke dalam masyarakat secara keseluruhan. Dengan demikian pengganti struktur opresif dari birokrasi yang terpisah dan antagonistik dari masyarakat, di dalam negara komunis fungsi birokrasi itu dilakukan oleh semua anggota masyarakat. Tugas - tugas administratif kehilangan sifatnya yang eksploitatif. Ia akan terdiri dari administrasi dari benda - benda bukannya administrasi dari orang - orang sebagaimana yang dilakukan oleh birokrasi selama ini.

Secara normatif, keberadaan pemerintah merupakan salah satu unsur dari tiga unsur penting berdirinya sebuah negara modern, disamping rakyat dan wilayah. Oleh rakyat yang bersangkutan, sebuah organisasi pemerintah diberikan kekuasaan (power) untuk menjalankan pemerintahan guna melayani kepentingan rakyat sebagai salah satu tugas pokoknya. Dalam menjalankan tugas tersebut sebuah pemerintahan harus mendasarkan pada peraturan perundangan yang berlaku agar tercapai ketertiban dalam proses pelaksanaannya. Inilah ciri sebuah pemerintahan modern yang membedakan dengan sebuah organisasi pemerintahan tradisional yang acuannya bukan rule of law tetapi sebuah kekuasaan atau kekuatan.

Menurut Kooiman (dalam Nawawi 2013 : 18) Kegiatan penyelenggaraan pemerintahan atau tata kelola pemerintahan (governance) merupakan serangkaian kegiatan 
(proses) interaksi sosial politik antara pemerintah dengan masyarakat dalam berbagai bidang yang berkaitan dengan kepentingan masyarakat dan intervensi pemerintah atas kepentingan kepentingan yang ada. Pemerintahan merupakan sebagai lembaga atau badan - badan publik dalam menjalankan fungsinya untuk mencapai tujuan negara, yang mana badan - badan publik tersebut meliputi kekuasaan legislatif, eksekutif dan yudikatif.

Kesamaan kepentingan dan cita - cita, perasaan senasib dan seperjuangan adalah salah satu alasan utama pembentukan sebuah negara dan bangsa. Begitupun pembentukan sebuah organisasi pemerintahan yang lahir sebagai konsekuensi praktis untuk mewujudkan kesamaan kepentingan dan cita - cita tersebut. Keberadaan organisasi pemerintahan tidak lebih dari sebuah alat untuk mewujudkan cita - cita bersama sebaga negara bangsa.

Rasyid (dalam Nawawi 2013 : 25) menyebutkan secara umum tugas - tugas pokok pemerintahan mencakup tujuh bidang pelayanan, sebagai berikut : Pertama, menjamin keamanan negara dari segala kemungkinan serangan dari luar, dan menjaga agar tidak terjadi pemberontakan dari dalam yang dapat menggulingkan pemerintah yang sah melalui cara cara kekerasan. Kedua, memelihara ketertiban dengan mencegah terjadinya gontok gontokan di antara warga masyarakat, menjamin agar perubahan apa pun yang terjadi di dalam masyarakat dapat berlangsung secara damai. Ketiga, menjamin diterapkannya perlakuan yang adil kepada setiap warga masyarakat tanpa membedakan status apa pun yang melatarbelakangi keberadaan mereka. Jaminan keadilan ini terutama harus tercermin melalui keputusan - keputusan pengadilan, dimana kebenaran diupayakan pembuktiannya secara maksimal, dan dimana konstitusi dan hukum yang berlaku dapat ditafsirkan dan diterapkan secara adil dan tidak memihak, serta dimana perselisihan bisa didamaikan. Keempat, melakukan pekerjaan umum dan memberi pelayanan dalam bidang - bidang yang tidak mungkin dikerjakan oleh lembaga non pemerintah, atau yang akan lebih bijak jika dikerjakan oleh pemerintah. Antara lain mencakup pembangunan jalan, penyediaan fasilitas pendidikan yang terjangkau oleh mereka yang berpendapatan rendah, pelayanan pos, dan pencegahan penyakit menular. Kelima, melakukan upaya - upaya untuk meningkatkan kesejahteraan sosial membantu orang miskin dan memelihara orang - orang cacat, jompo dan anak - anak terlantar, menampung serta menyalurkan para gelandangan ke sektor kegiatan yang produktif, dan sebagainya. Keenam, menerapkan kebijakan ekonomi yang menguntungkan masyarakat luas, seperti mengendalikan laju inflasi, mendorong penciptaan lapanga kerja baru, memajukan perdagangan domestik dan antarbangsa, serta kebijakan lain yang secara langsung menjamin peningkatan ketahanan ekonomi negara dan masyarakat. Ketujuh, 
menerapkan kebijakan untuk memelihara sumber daya alam dan lingkungan hidup, seperti air, tanah, dan hutan. Pemerintah juga berkewajiban mendorong kegiatan penelitian dan pengembangan untuk pemamfaatan sumber daya alam yang mengutamakan keseimbangan antara eksploitasi dan reservasi.

Menurut Blau (dalam Pasolong 2013 : 7), birokrasi adalah tipe organisasi yang dirancang untuk menyelesaikan tugas - tugas administratif dalam skala besar dengan cara mengkoordinasikan pekerjaan banyak orang secara sistematis.

Senada dengan itu Sinambela (dalam Pasolong 2013 : 7), mengatakan bahwa birokrasi adalah organisasi yang ditujukan untuk memaksimumkan efisiensi dalam administrasi. Setiyono (dalam Pasolong 2013 : 7), juga mengatakan bahwa birokrasi merupakan sebuah ruang mesin negara. Didalam berisi orang - orang (pejabat) yang digaji dan dipekerjakan oleh negara untuk memberikan nasehat dan melaksanakan kebijakan politik negara.

Kristiadi (dalam Pasolong 2013 : 7), mengatakan bahwa birokrasi adalah struktur organisasi di sektor pemerintahan, yang memiliki ruang lingkup tugas - tugas sangat luas serta memerlukan organisasi besar dengan sumber daya manusia yang besar pula jumlahnya. Birokrasi yang dimaksudkan untuk menyelenggarakan bernegara, penyelenggaraan pemerintahan termasuk didalamnya penyelenggara pelayanan umum dan pembangunan, seringkali oleh masyarakat diartikan dalam konotasi yang berbeda. Birokrasi seolah - olah memberi kesan adanya suatu proses panjang yang berbelit - belit apabila masyarakat akan menyelesaikan suatu urusan dengan aparat pemerintah.

Kartasapoetra (dalam Pasolong 2013 : 7), menyatakan birokrasi adalah pelaksanaan perintah - perintah secara organisatoris yang harus dilaksanakan sedemikian rupa sehingga dan secara sepenuhnya pada pelaksanaan pemerintahan melalui instansi - instansi atau kantor - kantor. Santoso (dalam Pasolong 2013 : 7), mendefinisikan birokrasi adalah keseluruhan birokrasi pemerintah, yang menjalankan tugas - tugas negara dalam berbagai unit birokrasi pemerintah di bawah departemen dan lembaga - lembaga non departemen, baik di pusat maupun di daerah, seperti ditingkat provinsi, kabupaten, kecamatan, maupun desa atau kelurahan. Atmosudirdjo (dalam Pasolong 2013 : 8), mengemukakan bahwa birokrasi mempunyai tiga arti yaitu : 1) birokrasi sebagai suatu tipe organisasi. Sebagai suatu tipe organisasi tertentu, birokrasi cocok untuk melaksanakan dan menyelenggarakan suatu macam pekerjaan yang terikat pada peraturan - peraturan yang bersifat rutin, artinya volume pekerjaan yang memerlukan keadilan merata dan stabil, 2) birokrasi sebagai sistem, yang 
artinya adalah suatu sistem kerja yang berdasar atas tata hubungan kerjasama antara jabatan jabatan (pejabat - pejabat) secara langsung kepada persoalannya dan secara formal serta jiwa tanpa pilih kasih atau tanpa pandang bulu, 3) birokrasi sebagai jiwa kerja, dalam hal ini merupakan jiwa kerja yang kaku, sebab cara bekerjanya seolah-olah seperti mesin, ditambah lagi dengan disiplin kerja yang ketat yang ketat dan sedikitpun tidak mau menyimpang dari apa yang diperintahkan atasan atau yang telah ditetapkan oleh peraturan - peraturan. Sedangkan yang dimaksud birokrasi pemerintah menurut Said (dalam Pasolong 2013 : 8) mengatakan seluruh jajaran badan - badan eksekutif sipil yang dipimpin oleh pejabat pemerintahan di bawah tingkat menteri.

Dari berbagai definisi birokrasi yang telah disebutkan diatas, maka dapat dirumuskan definisi birokrasi sebagai berikut : badan atau kantor maupun organisasi yang dipimpin oleh pejabat pemerintah dibawah menteri yang tugas utamanya memberikan pelayanan.

\section{Tugas Pokok Birokrasi}

Tugas pokok birokrasi adalah secara professional menindaklanjuti keputusan politik yang telah diambil pemerintah. Kabinet yang terdiri dari para menteri bukanlah birokrasi, kata Said (dalam Pasolong 2013 : 8), penjelasan UUD 1945 menyebutkan bahwa para menteri sebagai pemimpin Negara.

Terdapat dua istilah yang digunakan menyebut birokrasi pemerintah secara resmi, yaitu (1) aparatur Negara dan penyelenggara Negara. Istilah aparatur Negara misalnya digunakan pada jabatan menteri Negara pendayagunaan aparatur Negara. (2) penyelenggara Negara tataran suprastruktur yaitu lembaga - lembaga Negara yang secara enumerative disebut dalam UUD 1945 sebagai kewenangan dan fungsinya, ditugasi melaksanakan tugas pokok Negara.

Birokrasi pemerintahan dewasa ini, dimana para pejabat memainkan fungsi dan peran dengan menggunakan kekuasaan yaitu : jabatan, kewenangan dan legitimasi untuk mewujudkan pemerintahan yang efisien dan efekfif, dengan objek pemerintahan masa kini. Di dalam dunia pemerintahan modern, birokrasi biasanya memainkan peranan yang sangat penting, bahkan Etzioni (Pasolong 2013 : 9), mengemukakan bahwa :

Birokrasi dinilai sebagai alat yang paling efektif dalam melaksanakan kebijakan pemerintah. Di Negara - Negara yang sedang membangun peranan birokrasi yang sudah penting semakin bertambah penting dengan dijalankannya pula oleh birokrasi fungsi - fungsi 
lain di luar "policy implementation" seperti menjadi articulator dan agregator kepentingan, menjadi sumber informasi tentang "public issue and political events" sehingga mempengaruhi proses penyusunan kebijakan pemerintah, menjalankan sosialisasi politik, menjadi stabilisator politik, menjadi pengendali pembangunan, melakukan pelayanan public dan sebagainya.

Pendapat diatas menunjukkan bahwa selain peran tradisionalnya sebagai pelaksana kebijakan, birokrasi juga memainkan peranan politik. Dampaknya adalah birokrasi tidak hanya tumbuh menjadi besar dan kuat seiring dengan berkembangnya pembangunan, tetapi juga memiliki kekuasaan yang sangat luas. Menurut Rasyid (dalam Pasolong 2013 : 9) bahwa substansi pemerintahan adalah memberikan pelayanan kepada masyarakatnya.

Dengan konsepsi masyarakat modern menurut Weber birokrasi dipandang sebagai organisasi yang rasional, instrument kekuasaan yang paling utama dan ideal dalam rangka penyelenggaraan pemerintahan yang efisien dan efektif.

Yang dimaksud dengan efisien menurut Gibson (dalam Pasolong 2013 : 9) mencakup dua hal yaitu (1) criteria keefektifan harus mencerminkan keseluruhan siklus masukan proses - keluaran, tidak hanya keluaran, dan (2) criteria keefektifan harus mencerminkan hubungan timbal balik antara organisasi dan lingkungan sekelilingnya. Steers (dalam Pasolong 2013 : 9), menyatakan bahwa efektivitas suatu organisasi sebagai kemampuan organisasi tersebut memperoleh dan menggunakan secara efisien sumber - sumber yang tersedia untuk mencapai tujuannya. Stoner dkk (dalam Pasolong 2013 : 9), efektivitas adalah kemampuan untuk menentukan tujuan yang memadai melakukan hal yang tepat. Maxwell (dalam Pasolong 2013 : 9) efektivitas adalah landasan sukses. Dalam artian bahwa jika suatu organisasi mau manjadi sukses dan berkembang, maka harus didasarkan pada konsep yang sangat efektif.

Efisiensi menurut Robbins (dalam Pasolong 2013 : 10), adalah nisbah antara keluaran efektif dan masukan yang diperlukan untuk mencapainya. Ktaz dan Kahn dalam Steers (1985 : 2), membedakan dua jenis efisiensi, yaitu potensial dan aktual. Efisiensi potensial adalah tingkat efisiensi maksimal yang dapat dicapai oleh suatu organisasi secara tertulis dengan melihat keunikan, proses, produk dan tujuan organisasi tersebut. Efisiensi aktual adalah rasio biaya atau keuntungan yang secara riil dicapai oleh organisasi tersebut.

McDonald \& Lawton (dalam Pasolong 2013 : 10), menyatakan efisiensi adalah suatu keadaan menunjukkan tercapainya perbandingan terbaik antara masukan dan keluaran dalam suatu penyelenggaraan pelayanan publik. 
Kenyataan empirik menunjukkan bahwa efisiensi dan efektivitas birokrasi pemerintah belum dapat terealisasi, oleh karena adanya penyakit kronis yang menghampiri. Hal ini dapat dilihat kendala - kendala yang terdapat pada birokrasi administrasi publik, pelaksanaan pembangunan berlangsung demikian lamban atau mengalami banyak kegagalan, karena para birokrat dan lembaga usaha swasta ataupun masyarakat sendiri dapat dikatakan masih terjangkiti penyakit inefisiensi, yang seharusnya mereka masing - masing memperoleh kebebasan untuk menyembuhkan penyakit tersebut dengan menyesuaikan diri denga tata nilai baru administrasi publik yaitu pelayanan yang efisien kepada pelanggan.

Debirokratisasi menurut Kristiadi (dalam Pasolong 2013 : 11), adalah merupakan upaya untuk lebih menyederhanakan prosedur yang dianggap berbelit - belit tersebut. Sedangkan Kartasapoetra (dalam Pasolong 2013 : 11) mengatakan debirokratisasi adalah mengubah dalam artian menyesuaikan, (1) prosedur yang biasanya harus ditempuh secara berliku - liku dan menyulitkan, yang umumnya melesukan kegairahan, kegiatan dan kadang - kadang mematikan kreativitas, menjadi prosedur yang tidak bertele - tele yang memberikan kemudahan - kemudahan, kegairahan, kegiatan dan menimbulkan kreativitas - kreativitas baru dari para insan pembangunan yang justru ingin melihat, merasakan dan menikmati keberhasilan pembangunan, (2) prosedur birokrasi yang pada umumnya memerlukan pembiayaan tinggi (high cost), menjadi prosedur yang mantap dan singkat (wajar) ditempuh sehingga lebih meningkatkan dalam pembiayaannya (low cost), (3) prosedur birokrasi yang terbele - tele yang sering menimbulkan stagnasi dalam arus barang, arus jasa, arus dokumen, disamping pula menimbulkan daya serap yang rendah dari para aparatur dalam melaksanakan pembangunan, dengan dilaksanakan debirokratisasi kendala - kendala tersebut dapat segera disingkirkan, berubah menjadi tidak adanya stagnasi diatas sehingga penikmatan pembangunan dapat cepat terwujud dan dirasakan oleh segenap warga masyarakat, (4) prosedur birokrasi tertele -tele akan memaku para birokratnya di belakang meja tulisnya sehingga komunikasi menjadi sempit selain laporan yang akan diterima hanya sepihak (para petugas pengawasnya).

Dengan dilakukannya debirokratisasi maka pimpinan instansi, pimpinan perkantoran, demikian pula anggota aparaturnya pengemban fungsi dan tugas - tugas tertentu akan turun ke bawah (masyarakat) untuk menyebarkan komunikasi serta melakukan pendekatan pendekatan dengan masyarakat. Dengan demikian laporan tidak hanya diperoleh dari satu pihak melainkan dari dua pihak, sehingga pertimbangan - pertimbangan untuk mengambil 
suatu keputusan guna memperlancar pelaksanaan pembangunan dapat lebih cepat dan lebih mengena pada sasarannya.

Dalam konteks birokrasi pemerintahan, Randall B. Ripley dan Grace A. Franklin dalam bukunya Policy Implementation and Bureaucracy (dalam Wicaksono 2006 : 9) menyatakan bahwa birokrasi pemerintahan berhubungan dengan urusan - urusan publik. Pada level yang umum, apabila birokrasi memberikan pelayanan publik dengan baik maka birokrasi tersebut mampu menunjukkan sejumlah indikasi perilaku berikut :

1. Memproses pekerjaannya secara stabil dan giat;

2. Memperlakukan individu yang berhubungan dengannya secara adil dan berimbang;

3. Memperkerjakan dan mempertahankan pegawai berdasarkan kualifikasi profesional dan orientasi terhadap keberhasilan program;

4. Mempromosikan staff berdasarkan sistem merit dari hasil pekerjaan baik yang dapat dibuktikan;

5. Melakukan pemeliharaan terhadap prestasi yang sudah dicapai sehingga dapat segera bangkit bila menghadapi keterpurukan.

Sedangkan tujuan penyediaan birokrasi pemerintahan sebagaimana diuraikan oleh Ripley dan Franklin (dalam Wicaksono 2006 : 9) adalah sebagai berikut :

1. Menyediakan sejumlah layanan sebagai hakikat dari tanggungjawab pemerintah;

2. Memajukan kepentingan sektor ekonomi spesifik seperti pertanian, buruh atau segmen tertentu dari bisnis privat;

3. Membuat regulasi atas berbagai aktivitas privat;

4. Meredistribusikan sejumlah keuntungan seperti pendapatan, hak - hak, perawatan medis dan lain - lain.

\section{Pembahasan}

Dalam proses penyelenggaraan pemerintahan keberadaan birokrasi yang profesional menempati posisi sentral dan strategis untuk mewujudkan pemerintahan yang baik, bersih, melayani, efektif dan efisien, terbuka untuk dikontrol dan dikoreksi oleh masyarakat. Secara umum kualitas peran dan fungsi birokrasi dalam keseluruhan proses penyelenggaraan pemerintahan memang berkurang jumlahnya tetapi secara kualitatif justru semakin penting. Misalnya peran dan fungsi birokrasi pemerintahan dalam proses pemberdayaan masyarakat, melalui penciptaan barang - barang publik yang berkualitas dalam jumlah yang cukup. Jika 
sekarang kecenderungannya mengajak semua stakeholders untuk terlibat dalam proses tersebut.

Artinya pemerintah melalui birokrasinya tidak lagi menempatkan diri dalam posisi terdepan dalam menyediakan barang - barang publik, tetapi lebih berusaha mendorong pihak lain untuk tampil di depan. Dalam hal ini pemerintah berusaha menjadi stimulator, fasilitator, dan dinamisator (katalisator) bagi semua stakeholders (pemangku kepentingan) untuk bersama - sama menyediakan barang - barang publik. Jangan dikira pergeseran peran ini menjadikan tugas birokrasi menjadi lebih ringan, justru sebaliknya semakin berat. Secara substantif peran dan fungsi demikian tentu lebih sulit dan tentunya lebih sulit dimainkan aparatur birokrasi, kecuali aparatur birokrasi untuk terus berusaha menempa dirinya, dengan meningkatkan kualitas pendidikan, dan lebih penting adalah mengubah perilakunya. Jika sejumlah prasyarat yang mengikuti pergeseran peran itu tidak bisa dipenuhi, terutama oleh pihak birokrasi, maka akan muncul sejumlah komplikasi persoalan manajemen. Bagaimana bisa menjadi stimulator dan fasilitator jika pola pikir dan perilaku birokrasi masih saja seperti dulu. Bisa juga sebaliknya, bukannya mereka tidak mau berubah, tetapi tidak tahu harus bagaimana untuk berubah dan sejauh mana perubahan itu harus dilakukan. Disinilah peran manajemen sangat penting untuk mengarahkan dan mengotrol proses perubahan kelembagaan dan perilaku birokrasi.

Prinsip manajemen publik baru yang ditawarkan Osborne dan Gaebler dengan konsep steering rather than rowing. Dengan cara itu diharapkan tercipta efisiensi, efektivitas dan tingkat ekonomis (value and money) yang lebih tinggi dibandingkan jika semua itu dikerjakan sendiri oleh birokrasi.

Terjadinya transformasi peran dan fungsi birokrasi pemerintah dari pelaksana berubah menjadi pengarah (steering), tidak berarti menjadikannya kedudukan strategis birokrasi berkurang, karena ia justru beralih memainkan peran dan fungsi lain yang secara substansial jauh lebih penting dan menantang. Dalam keseluruhan proses pemerintahan itu aktor - aktor utamanya tidak lagi didominasi oleh birokrasi, tetapi semua aktor atau stakeholders diharapkan ikut berperan aktif, sementara pemerintah melalui birokrasinya diharapkan dapat menjadi katalisator. Sebagai katalisator ini berarti birokrasi bersama - sama dengan semua stakeholders yang ada berusaha mewujudkan tujuan pemerintahan secara efektif, efisiensi, dan ekonomis, sehingga keseluruhan proses pemerintahan dapat lebih di tingkatkan kualitas dan kuantitasnya. 
Idealnya semakin banyak tugas - tugas pemerintahan yang dikembalikan kepada publik berarti semakin baik, sehingga pemerintah bisa lebih fokus pada kegiatan publik tertentu yang secara objektif memang hanya pas jika diserahkan sepenuhnya kepada pemerintah. Lagi pula dengan begitu besarnya tugas dan fungsi pemerintah, maka tugas dan fungsi itu perlu didelegasikan, tidak hanya kepada struktur pemerintahan yang ada di bawahnya, tetapi juga juga kepada masyarakat. Idealnya struktur birokrasi itu semakin ramping, sehingga aktivitasnya semakin lincah dan efisien. Hal demikian bukannya tidak disadari oleh manajemen, tetapi lagi - lagi implementasinya yang terasa begitu sulit dilakukan. Tidak jarang muncul sejumlah pertimbangan yang sifatnya non manajemen, yang menjadikan sosok birokrasi pemerintahan, terutama di negara berkembang itu terlihat tambun dan gembrot.

Dalam kasus Indonesia, struktur birokrasi yang ada masih dirasakan gembrot dan lamban. Sejumlah upaya dilakukan untuk mengatasi persoalan ini, tetapi yang terjadi sering kali dampak sampingan karena buruknya alokasi personil, sehingga ada daerah yang kekurangan pegawai, dan ada sementara daerah yang berlebihan. Jika ditotal secara umum dibandingkan dengan ketubuhan, mungkin saja terlihat relatif ramping, tetapi karena buruknya alokasi menyebabkan sosok birokrasi itu gembrot dan lamban kinerjanya. Lagi pula upaya perampingan birokrasi ini tidak otomatis berarti dilakukan pengurangan personil dalam jumlah besar - besaran, meskipun itu diperlukan, tetapi yang jauh lebih penting adalah menata struktur organisasi agar lebih ramping, efektif, dan efisien dalam menjalankan tugas dan fungsinya.

Pada dasarnya organisasi pemerintahan adalah organisasi dalam skala besar, namun tidak berarti bisa membesar begitu saja tanpa alasan yang tepat. Yang terjadi sekarang adalah organisasi pemerintahan itu terus tumbuh membesar dan membesar, sehingga sesuatu fungsi dan kegiatan tertentu yang sebenarnya bisa dikerjakan secara efektif oleh satu dua orang ternyata dikerjakan secara keroyokan oleh banyak orang. Inilah yang disebut struktur birokrasi yang gembrot dan tidak efektif dalam menjalankan peran dan fungsinya. Demikian juga sesuatu kegiatan publik yang secara teoretik lebih efektif jika diserahkan kepada masyarakat, atau sebagiannya dikerja samakan denga pihak lain, ternyata masih dikerjakan oleh aparatur birokrasi, sehingga struktur birokrasi itu seperti merambah ke semua tempat dan kegiatan, mendominasi dan berpretensi melakukan semua kegiatan yang dengan serta merta mendapat label sebagai kegiatan publik. Padahal, sebagaimana prinsip Manajemen Publik Baru, sejumlah urusan yang sebelumnya ditetapkan menjadi urusan pemerintahan itu 
tidak harus dikelola semata oleh pemerintah, bahkan beberapa di antaranya perlu diserahkan sepenuhnya kepada swasta atau masyarakat.

Barangkali ini sebuah "kutukan" dari pola pikir lama yang sejak awal meyakini bahwa persoalan yang diurusi adalah kepentingan negara yang menyangkut semua hal, sehingga struktur birokrasi memang dirancang demikian besar dan menjangkau ke mana mana. Barangkali itulah "kutukan" dari sebuah birokrasi pemerintahan yang pada hakikatnya memiliki tugas pokok dan fungsi yang besar dalam konteks negara yang bersangkutan. Kristiadi mengatakan bahwa pada hakekatnya birokrasi merupakan struktur organisasi di sekitar pemerintahan yang memiliki ruang lingkup tugas sangat luas serta memerlukan organisasi besar dengan sumber daya manusia yang besar pula jumlahnya. Semua itu dimaksudkan untuk melaksanakan penyelenggaraan bernegara, penyelenggaraan pemerintahan termasuk di dalamnya penyelenggaraan pelayanan umum dan pembangunan.

Sampai sejauh ini birokrasi adalah sebuah organisasi besar dengan pengaruh dan kekuatan yang juga sangat besar serta menentukan jalannya proses pemerintahan. Apalagi di negara berkembang dan masih menganut manajemen pemerintahan tradisional, peran dan fungsi birokrasi itu akan terlihat begitu besar. Dalam hal jumlah peran yang dimainkan secara langsung, maka peran birokrasi di negara berkembang jauh lebih besar dari peran serupa yang dimainkan birokrasi di negara yang sudah maju ini secara tidak langsung, manajemen publik baru itu memang dirancang untuk mengurangi sejumlah peran pemerintahan yang sebelumnya berada di pusat kekuasaan, kemudian digeser atau didelegasikan kepada pemerintahan daerah atau bahkan kepada masyarakat.

Secara tidak langsung denga dianutnya konsep Manajemen Publik Baru, telah menggerus atau mengurangi peran dan fungsi birokrasi, terutama dari sisi jumlah dan derajat ikut campur dari tangan - tangan birokrasi. Manajemen publik baru itu berusaha melibatkan semua stakeholders, sesuai dengan kapasitas dan kapabilitasnya, dengan pertimbangan efisiensi dan efektivitas penyelenggaraan kegiatan, sehingga suatu kegiatan tertentu bisa saja kemudian diserahkan sepenuhnya kepada pemerintah daerah dengan hak dan tanggungjawab yang besar dalam mengelola dan mempertanggungjawabkan. Hal serupa juga bisa berlaku atau diberikan kepada organisasi swasta atau masyarakat sipil, dimana pemerintah hanya melakukan supervisi atau bahkan menyerahkan sepenuhnya dalam arti tidak ikut campur secara teknis dan menyerahkan sepenuhnya dalam arti tidak ikut campur secara teknis dan menyerahkan sepenuhnya kepada mekanisme pasar. Tidak berarti peran dan fungsi birokrasi itu tidak lagi penting, melainkan hanya berkurang pada beberapa bagiannya yang dianggap 
tidak pas jika masih dipegang birokrasi. Selanjutnya birokrasi itu melakukan reposisi atau mengubah dirinya dengan melakukan transformasi peran dan fungsinya ke arah yang lebih substantif.

Penerapan konsep New Public Management akan menyebabkan terjadi perubahan manajemen sektor publik yang drastis dari sistem manajemen tradisional yang kaku, birokratis, dan hierarkis menjadi model manajemen sektor publik yang fleksibel dan lebih mengakomodasi pasar. Penerapan konsep NPM dapat dipandang sebagai suatu bentuk modernisasi atau reformasi manajemen dan administrasi publik, depolitisasi kekuasaan, atau desentralisasi wewenang yang mendorong demokrasi. Perubahan tersebut juga telah mengubah peran pemerintah terutama dalam hal hubungan antara pemerintah dengan masyarakat.

\section{E. Kesimpulan}

Konsep New Public Management pada dasarnya mengandung tujuh komponen utama, yaitu :

1. Manajemen profesional di sektor publik;

2. Adanya standar kinerja dan ukuran kerja;

3. Penekanan yang lebih besar terhadap pengendalian output dan outcome;

4. Pemecahan unit - unit kerja di sektor publik;

5. Menciptakan persaingan di sektor publik;

6. Pengadopsian gaya manajemen di sektor bisnis ke dalam sektor publik;

7. Penekanan pada disiplin dan penghematan yang lebih besar dalam menggunakan sumber daya.

Konsep New Public Management sejalan dengan sepuluh prinsip yang diusulkan oleh Osborne dan Gaebler mengenai reinventing government, antara lain : pemerintahan katalis, pemerintahan milik masyarakat, pemerintahan yang digerakan oleh misi, pemerintahan yang berorientasi pada hasil, pemerintahan yang berorientasi kepada pelanggan, pemerintahan wirausaha, pemerintahan yang antisipatif, pemerintahan yang terdesentralisasi, dan pemerintahan yang berorientasi pasar.

Unsur yang perlu diperhatikan yang merupakan penentu dalam mewujudkan pencapaian cita - cita suatu pemerintahan adalah sebagai berikut :

1. Pemimpin yang amanah;

2. Mengikis budaya organisasi yang buruk;

3. Mengajak masyarakat turut berpartisipasi dalam pembangunan; 
4. Tidak alergi untuk dikritik;

5. Berani menanggung resiko dalam pekerjaan.

Penerapan konsep reinventing goverment membutuhkan arah yang jelas dan political will yang kuat dari pemerintah dan dukungan masyarakat. Yang terpenting adalah adanya perubahan pola pikir dan mentalitas baru di tubuh birokrasi pemerintahan itu sendiri karena sebaik apapun konsep yang ditawarkan jika semangat dan mentalitas penyelenggara pemerintahan masih menggunakan paradigma lama, konsep tersebut hanya akan menjadi slogan kosong tanpa membawa perubahan apa - apa.

\section{DAFTAR PUSTAKA}

Ali, Faried. 2011. Teori dan Konsep Administrasi. Jakarta, PT. Raja Grafindo Persada.

Mustafa, Delly . 2014. Birokrasi Pemerintahan. Bandung, Penerbit Alfabeta.

Nawawi, Zaidan. 2013. Manajemen Pemerintahan. Jakarta, PT. Raja Grafindo Persada.

Syafiie, Inu Kencana. 2003. Kepemimpinan Pemerintahan Indonesia, Penerbit PT. Refika Aditama. Bandung.

. 2013. Sistem Administrasi Negara Republik Indonesia (SANRI), Penerbit Bumi Aksara. Jakarta.

2015. Ilmu Administrasi, Penerbit Pustaka Pelajar. Yogyakarta.

Pasolong, Harbani, 2013. Kepemimpinan Birokrasi. Bandung. Alfabeta.

Thoha, Miftah. 2014. Birokrasi dan Politik di Indonesia. Jakarta, PT. Raja Grafindo Persada.

Wicaksonon, Kristian Widya. 2006. Administrasi dan Birokrasi Pemerintah. Yogyakarta, Graha Ilmu. 